\title{
Globalization and Bankruptcy of SMEs in Slovakia
}

\author{
Jaroslav Dado ${ }^{1}$, Lenka Hvolkova ${ }^{1,}$, and Janka Taborecka ${ }^{1}$ \\ ${ }^{1}$ Faculty of Economics, Department of Corporate Economics and Management, Matej Bel University, \\ Tajovskeho 10, 975 90, Banska Bystrica, Slovakia
}

\begin{abstract}
.
Research background: Globalization - the process of increasing social, cultural, political, and economic interdependence - has resulted in several changes in business environment. Global market opportunities and threats are major effects of globalization; they refer to the increases in market potential, trade and investment potential and resource accessibility. Global market threats refer to the increases in the number and level of competition, and the level of uncertainty. Global competitors can have the impact on bankruptcy of local SMEs in less developed or smaller countries. Are globalization in economics and company bankruptcy related? In the past, the cause of bankruptcy was mainly in the company itself. The development of globalization has brought a number of positive as well as a number of negative consequences for several areas of society. Is one of the negative effects of globalization the bankruptcy of companies?

Purpose of the article: The paper presents a classification of external and internal causes of bankruptcy and indicators of the threat of company bankruptcy. The paper also focuses on the results of the research analysis about the causes of small and medium-sized enterprises mortality in Slovakia and the impact of globalization factors as the causes of their bankruptcy. The analysis of bankruptcies is oriented on the research of the causes of small and medium-sized enterprises mortality in Slovakia and the influence of globalization factors as the causality of their bankruptcy.

Methods: The research sample presents structured interview with 16 SMEs' owners. They identified more aspects of globalization impact to Slovak SMEs bankruptcy.

Findings \& Value added: The results of research indicate that there is an evidence of impact of globalization on the bankruptcy of SMEs in Slovakia, but there are some differences among various industries.
\end{abstract}

Keywords: bankruptcy; competitors; globalization

JEL Classification: $D 22 ; F 10 ; F 61 ; G 33$

\footnotetext{
*Corresponding author: lenka.hvolkova@umb.sk
} 


\section{Introduction}

Globalization - the process of increasing social, cultural, political, and economic interdependence - has resulted in several changes in business environment. The process of globalization of the world economy is characterized by rapid qualitative and quantitative changes; modern economic relations are regulated by a large number of economic and legal regulators, and especially in this progressive part as an innovative direction [1,2]. Globalization supposes the creation of a transnational single market guided by the principles of free trading and enhanced by dynamic flows of exchange of information, which offers the opportunity for organizations and individuals to carry out practically any kind of economic transaction, without having to be subordinated to national borders [3]. Global market opportunities and threats are one of major globalization effects. While the former refers to the increases in market potential, trade and investment potential, and resource accessibility, the latter refers to the increases in number and level of competition, and the level of uncertainty [4]. Given these changes, globalization brings about a borderless world [5].

Liberalization of world trade and capital markets led by globalization has created a new and challenging competitive arena for all companies. These aforementioned trends have brought about two key effects of globalization, global market opportunities and global market threats [6]. It is obvious that globalization presents not only more opportunities to firms, but also higher levels of threats $[7,8]$, that can visible influence mostly small and medium sized enterprises - regarded as the engine of economic growth and employment [9]. In the light of their smaller size, most SMEs lack the capabilities, market power and other resources of the traditional multinational enterprise [10].

Positive effect of globalization enables firms to outsource and find customers around the world. Although globalization is a worldwide phenomenon, the extent to which each country is globalized is not identical [11]. To measure the degree of globalization of each nation, a globalization index was recently developed by more institutions. One of the relevant is KOF or Statista globalization index. Both information sources are very similar. Process of globalization opened borders in the world. This process brought new stronger competition to local entrepreneurs.

On one side, global market opportunities refer to the increases in market potential, trade and investment potential and resource accessibility $[12,13]$. On the other side, global market threats refer to the increases in the number and level of competition, and the level of uncertainty $[8,14,15]$. Global business players can create alliances with home entrepreneurs on local markets. In the same time, the same players develop competitive pressure to home entrepreneurs. Not infrequently is the result of competitive pressure bankruptcy of many local entrepreneurs. Business failure is perceived as unwanted but existing element of all economies in the world, on the other hand, this can be also negative aspect of globalization [16].

Global competitive threats are defined as the intensified competition in global markets resulting from larger numbers of competitors in the global marketplace [11,17].

The Swiss Institute of Technology in Zurich every year makes the list of globalization index. In 2019 Slovakia had globalization index 83,07. It is $12^{\text {th }}$ place in global ranking [18].

Nineties years of last century are characterised in East European countries (including Slovakia) by transformation of their economics. This process has led to the change of the economic mechanism into a market economy, which in itself has meant a gradual, more or less rapid opening of markets [19]. Therefore, companies in the Slovak Republic had to adapt not only to the changing state system, but also to the 
harsh emerging competitive environment [20]. Opening of their markets accelerated globalization process and the process has almost exponential dynamics.

Almost nobody from authors writing about small business failures not illustrate the external factor competition of global market players as a bankruptcy risk factor.

Open market was big opportunity for global distribution networks. As the first started in Slovakia companies as K-mart, Tesco, Bila, Carefour, Hypernova or Lidl. They brought new philosophy of purchasing, new technologies, new communication strategies, new economic power, new quality of offer, new business formats, higher innovative ability, new brands, better knowledge of customers, more new attractions for customers, and experiences from other foreign markets. Foreign global players producers created networks with global retailers operating in Slovakia.

Large global retailers with their economic power were strong competitors to small local retailers. Many of local enterprises finished their business activities. Owners of small shops in down town closed business under influence of new shopping centres.

Next stage of globalization was process of privatization. Large Slovak companies bought Slovak or global foreign investors. Slovak investors failed to manage large private companies. Moreover, large foreign owners of privatised Slovak companies changed their strategy. They closed many local companies. In this category under pressure of global players were closed companies Tesla, Calex, Armatúrka Myjava, more breweries, creameries, bakeries, cement plants, freezers, meat industry, furniture producers, including banks or insurance companies. Reason why they were closed is their bankruptcy.

War of Slovak companies with global player won companies with good marketing, good business strategy and with experiences from foreign markets only.

\section{Methodology}

The aim of the research was to identify how globalization affected Slovak SMEs. If the global competitors affected the level of SMEs bankruptcy.

Identification questions for surveyed sample were:

How old is your company? How long is operating your company on the market? How is your legal form? What is your territorial scope? (local, regional, national, international, global); How is your market share on your target market? $(1-20 \%, 21-40 \%, 41-60 \%, 61-$ $80 \%, 81-100 \%)$.

After analysis of secondary data research team used qualitative method - structured interview with the sample of SMEs' owners in Slovakia. As the first aim was identification of subject (company size, age of company, legal form, industry, market share, territorial scope). All sample of interviewed SMEs have Slovak owners. All SMEs are operating on Slovak market (except freight truck carries) only. All SMEs are smaller than 50 employees with the year turnover less than 1 mil. $€, 12$ participants are legal entities - limited companies and 4 are natural persons. For all enterprises, their market share is less than $20 \%$.

Surveyed sample of SMEs was:

3 freight truck transporters

3 retail stores - food

1 gas service

1 lift service

2 audit of accounting

1 soft drinks production

1 currier

1 heaters sale, installation and service 
1 petrol station

1 car dealer

1 waste disposal

After company identification, we discussed following questions:

Do you have direct competitors - global players on the Slovak market? (yes, no)

How many direct global competitors do you have? (zero, 1-5, 6-10, more than 10)

How the globalization has affected your business? (open question)

Has globalization threatened your business? (open question)

How global players have affected your company? (open question)

Do you cooperate with global players on the Slovak market? (yes, no, other...)

Have global players reduced your turnover? (very much - much - not much - no)

\section{Results and discussion}

From previous, realise research based secondary and primary data sources we can present the main causes of SMEs bankruptcy in Slovakia from 1990s included:

- Managerial inexperience of business owners

- Non-competitive offer with lower quality of products and services

- Weak or no innovation

- Weak or no marketing

- Surplus of staff in administration and other non-productive activities

- Too strong family style of management

- Secondary insolvency

- Realised methods of privatization

- Pressures of foreign competitors

- Radical legislative regulation some aspects of business

- Targeted "tunnelling" of business by its owners directly or through related companies

- Purchasing of unnecessary or overpriced investments and services

- Inadequate person consumption

- Bad business location

- The misconception that the business will operate on its own

The group of risk indicators presenting the threat of bankruptcy, which is visible even from the point of view outside of the company, are:

- Frequent changes in the position of managing director in the company

- Frequent changes in the company's accounting officer

- Decrease in market share

- Non-compliance with delivery deadlines

- Nomination to the company management people of the "kinder management" category

- Demonstrative consumption, e.g. in the form of the purchase of luxury vehicles, expensive holidays or other personal consumption

- Stopping of investments or starting reckless investments

- Illogical diversification of the company's activities

- Loss of large business partners

- Frequent and illogical price increasing or reduction

- Transfers of assets beyond the reach of creditors

Internal indicators of bankruptcy risk include: 
- Decreasing of volume and profit rate until loss is reported

- Decreasing of sales volume

- Decreasing of the own equity amount and increase of the foreign sources share

- Problems with the payment of liabilities (invoices, loan repayments, non-payment of wages and taxes)

- Increasing the need for additional external resources to repay liabilities increasing of indebtedness

- Problems with obtaining of additional foreign resources and postponing their repayment

- Pressure from suppliers for advance payments

- Increasing of the amount of penalty interests and other sanctions

- Delays in payments from customers

- Non-compliance with the delivery date

- The need to sell fixed assets below market price

- Increasing of the employee turnover rate

Research focused to the influence of globalization to bankruptcy of selected sample from SMEs in Slovakia showed, that all surveyed SMEs have direct global competitors on their local and international market. Moreover, mainly freight truck transporters; petrol station and car dealer have more than 10 direct global competitors on the Slovak market. SMEs that are providing gas services lift services, heater sale and services have less than 5 direct global competitors on the Slovak market identified. Global companies represent global direct competitors; they have stronger negotiation power with global companies operating on the Slovak market (f.e. lift service companies as Otis or KONE received order from global player operating on the Slovak market easier than a local SME).

Respondents have also declared, that global players operating on the Slovak market "took" Slovak SME's orders. The worst situation is among retail stores, because two from three-surveyed company are closed. They have lost customers due to their movement to the supermarkets. One company (currier) was sold to global player in this branch. Slovak SMEs have not economic power to compete them. Audit of accounting companies lost order from bigger Slovak companies. Their former clients received members of Big 4. Owner of soft drinks company closed his business under the press of global competitors operating on the Slovak market. Global players forced local restaurants with agreement. The agreements limited restaurants to buy soft drinks from global player brand only. Interviewed owner of soft drinks company presented more similar examples.

For Slovak SMEs is this market after the arrival of global players (direct competitors) narrower. Global players exert pressure to the prices of Slovak SMEs offer. Slovak SMEs have chance to cooperate with large global players operating on Slovak market as material and spare parts suppliers only. Positive effect of global players operating on the Slovak market is their indirect pressure to service quality increasing.

Almost all of surveyed SMEs answered that the additional influence of global players was high or very high reduction of their turnover. The situation has normalized for freight truck carriers during the last two years. Global players brought to Slovakia, valuated as positive effect by surveyed SMEs, franchising system (with all its positive effects) for network development of petrol stations, car dealers and shops.

\section{Conclusion}

Surveyed entrepreneurs formulated some common conclusion from interview during interview. Here are some answers: 
- "Globalization is not the main reason of my SMEs bankruptcy", answered entrepreneurs. However, it is very important factor. For three surveyed entrepreneurs are global competitors operating on their market direct causes of their bankruptcy only.

- "Globalization has increased my firm's opportunities to access raw materials and spare parts worldwide."

- "Globalization has increased the level of competition my company is facing."

- "Globalization has increased on the Slovak market the number of competitors my company is facing."

- "Globalization has increased my firm's opportunities to expand the firm's products and/or markets worldwide."

- "Global players they have stronger negotiation position with potential customers, especially when customers are global players too."

- "Positive affect of globalization in Slovakia is creation many new SMEs based on the franchising."

- " "Global player brought on the Slovak market pressure to higher quality of services."

VEGA No. 1/0468/18 Analysis of the cause of bankruptcy among small and medium-sized enterprises in the Slovak Republic

\section{References}

1. Tarasenko, O., Yermakov, Y., Pchelin V. (2017). Formation of competitive advantages of enterprises in terms of globalization: Competitive dynamics and an intellectual component. Baltic Journal of Economic Studies, 3(5), 469-473.

2. Berghoff, H. (2016). Moderne Unternehmensgeschichte. Berlin: De Gruyter Oldernbourg.

3. Cervantes, M.P.A., Lopez, R.N., Rambaud, C.S. (2020). The effect of globalization on economic development indicators: An inter-regional approach. Sustainability, 12(5), 1 18.

4. Thoumrungroje, A. (2001, May). The Effects of Globalization on Marketing Strategy and Performance. Washington State University. Retrieved from: https://citeseerx.ist.psu.edu/viewdoc/download?doi=10.1.1.629.6471\&rep=rep1\&type= pdf

5. Eden, L., Lenway, S. (2001). Introduction to the Symposium Multinational: The Janus Face of Globalization. Journal of International Business Studies, 32(3), 383-400.

6. Molle, W. (2002). Globalization, Regionalism, and Labour Markets: Should We Recast the Foundations of the EU Regime in matters of regional (rural urban) development? Regional studies, 36(2), 161-172.

7. Eng, H. E. (2002). Global Development Issues in a Changing World. Journal of Macromarketing, 21(2), 213-16.

8. Jones, M. T. (2002). Globalization and Organizational Restructuring: A Strategic Perspective. Thunderbird International Business Review, 44(3), 325-51.

9. Lee, Y., Shin, J., Park, Y. (2012). The changing pattern of SME's innovativeness through business model globalization. Technological Forecasting and Social Change, $79(5), 832-842$.

10. Knight, G. (2000). Entrepreneurship and Marketing Strategy: The SME under Globalization. Journal of International Marketing, 8(2), 12-32. 
11. Hafsi, T. (1999, November). Global Competition and the Peripheral Player: A Promising Future. The Egyptian Centre for Economic Studies. Retrieved from: https://citeseerx.ist.psu.edu/viewdoc/download?doi=10.1.1.198.9566\&rep=rep1\&type= pdf

12. Fawcett, S.E., David, J.C. (1993). Coordinated Global Manufacturing, The Logistics/Manufacturing Interaction, and Firm Performance. Journal of Business Logistics, 14(1), 1-25.

13. Levitt, T. (1983). The Globalization of Markets. Harvard Business Review, 61(3), 92102.

14. Perlmutter, H.V., Heenan, D.A. (1986). Cooperate to Compete Globally. Harvard Business Review, 64(2), 136-152.

15. Akopov, N.E. (2008). Globalization Trends and Competitive Technologies of Transnational Groups of Auto Companies' Positioning. Tomsk State University Journal, (316), 127-135.

16. Karpáč, D., Bartošová, V. (2020). The verification of prediction and classification ability of selected Slovak prediction models and their emplacement in forecasts of financial health of a company in aspect of globalization. In T. Kliestik (Eds.), $19^{\text {th }}$ International Scientific Conference Globalization and Its Socio-Economic Consequences 2019 - Sustainability in the Global-Knowledge Economy (pp. 1-7). SHS Web of Conferences 74. Cedex: EDP Sciences.

17. Mesa, A.O. (2005). Globalization and the Internationalization of the Company: Is a New Paradigm Necessary? Estudios Gerenciales, (96), 127-137.

18. w. a. (2020, May 20). Leading countries in the Globalization Index field of economic globalization 2019. Statista. Retrieved from: https://www.statista.com/statistics/268171/index-of-economic-globalization/

19. Nový, M. (2020). The influence of globalization on selected constitutive and regulating elements of the economic mechanism on the example of regional economic growth of new and old member states of the European Union. In T. Kliestik (Eds.), $19^{\text {th }}$ International Scientific Conference Globalization and Its Socio-Economic Consequences 2019 - Sustainability in the Global-Knowledge Economy (pp. 1-8). SHS Web of Conferences 74. Cedex: EDP Sciences.

20. Adamko, P., Chutka, J. (2020). The verification of prediction and classification ability of selected Slovak prediction models and their emplacement in forecasts of financial health of a company in aspect of globalization. In T. Kliestik (Eds.), $19^{\text {th }}$ International Scientific Conference Globalization and Its Socio-Economic Consequences 2019 Sustainability in the Global-Knowledge Economy (pp. 1-9). SHS Web of Conferences 74. Cedex: EDP Sciences. 